\title{
A Study on the Chinese Ethical Evolution and Its Effects on SMB in China Today
}

\author{
Kenneth Wall \\ Institute for Advanced Studies \\ Colorado Technical University \\ Colorado Springs, CO 80907, U.S.A. \\ Hua Lin, Runtong Zhang \& Xi Lei \\ School of Economics and Management \\ Beijing Jiaotong University \\ Beijing 100044, China \\ E-mail: mendson@sina.com
}

\begin{abstract}
As a result of economic reform commencing in 1978 in China, ethical behavior of the Chinese businesses is changing. The influence of Confucianism, Taoism, Sunzi Bingfa, and belief in a Heavenly God is reviewed based on data gathered from small and medium sized business during the Summer of 2006. Most Chinese businesses are small and family-owned, and in part, the emphasis on family ownership comes from the Confucianism beliefs of the importance of family. Taoism and Sunzi Bingfa are traditional Chinese beliefs that influence business decisions to varying degrees. Information was also gathered on the frequency of use of Guanxi and the importance of Face. Guanxi is a term meaning "connections" and has been a very important aspect of doing business in China and may be increasing in recent years. "Face" is a term used to show respect to both subordinates and superiors and has been very important through the ages, but it may be losing some relevance. These aspects of culture are reviewed in consideration of the change from a planned economy to a market based economy.
\end{abstract}

Keywords: China, Culture, Ethics, Business

\section{Introduction}

The Chinese economy is evolving and undergoing major change and growth as a result of the conversion from a planned economy to a market economy. It is important to understand the impact of these changes to the society and in particular how conduct of business in China is being impacted.

The growth of the Chinese economy is unparalleled. The framework of Chinese thought must be understood when conducting business in China. It is important to both Chinese and Western business people alike when engaging in business practices. Understanding the cultural and ethical backgrounds of business leaders is paramount when negotiations are progressing to ensure a meeting of the minds.

This research was initiated to examine evolving ethical business practices in China. A brief description of the changes on-going in that economy is presented as a background for understanding the evolving Chinese economy.

The Chinese culture is an ancient one dating back more than 4,000 years. Some aspects of the culture are predominantly Chinese even though other cultures have adopted portions of these Chinese cultural features to a lesser degree. Confucianism and Taoism are amongst the numerous beliefs that are a part of the culture. Sunzi Bingfa teachings of military strategy are applied in business as well as military operations. Guanxi means good connections or relationships and have a substantial impact on the society. "Face" is the term used to describe ones dignity and prestige and is very important. Giving face is an excellent means to improve Guanxi. These considerations provide a conceptual framework for the study of how "Chinese Ethical Evolution in Business" is progressing. 
A critical review of literature was conducted by Kenneth Wall that reviews recent publications concerning the Changes in Chinese culture occurring as a result of the economic reforms taking place in China. Excerpts are quoted herein for additional background information as deemed appropriate by the authors.

There has been much literature, especially monthly periodicals, which speculate on the changes in the culture occurring as a result of the evolution of the Chinese economy from planned to market. A primary objective of this research is to verify and quantify those changes as being real or imagined. As Jinglian Wu noted "As China's development is having and will continue to have significant impact to the global economy, people, whatever their attitude toward China, are eager to know and understand how the change and growth were made possible. However, understanding China's economy, particularly its reform and development, is not easy." (Wu, 2005, Preface). When making business decisions in light of a changing economy and the subsequent change in the culture, it is imperative to act from a basis of fact rather than fiction.

The goals of the research are to:

- Identify aspects of the Chinese business culture that are changing.

- Provide a statistical basis for determining how those aspects of the Chinese culture are changing.

- Interpret those changes and provide insights into the impact of those changes in conduct of business in China.

\section{Research methodology}

To investigate the changes evolving in Chinese business ethics, the researchers prepared a questionnaire that was mailed to over 5,000 businesses throughout China. 106 responses were received by returned mail. 16 of the 106 had not adequately completed the form to include them in the final statistics. The statistics quoted in this research are based on the 90 forms that were deemed representative of the answers to all or most questions.

Four criteria were used for selecting companies to whom the questionnaire was sent.

1) The number of employees were divided into two groups of $0 \sim 100$ and 101 500 to ensure representation for small and medium size business were included.

2) The business types were based according to the Chinese government's classification: Manufacturer, Sales/Trading/Restaurant, and Service industries (including Information Technology, Tourism, and Entertainment).

3) The ownership types included: Sole Proprietor, Limited Partnership, Corporation, Joint Ventures, and State-owned Enterprises.

4) Location were classified as Coastal province or Inland province

Through the database from Chinese Post office, five thousand companies with the following distribution were selected:

Inland manufacturer (with no more than 100 employees): 241

Inland manufacturer (100 500): 388

Coastal manufacturer (0 100): 500

Coastal manufacturer (100 500): 282

Inland sales (0 100): 695

Inland sales (100 500): 182

Coastal sales (0 100): 205

Coastal sales (100 500): 678

Inland service (0 100): 902

Inland service $(100 \sim 500): 35$

Coastal service (0 100): 731

Coastal service (100 500): 143

Total: 5028

Wrong address: 213

As an example, the process of selection was to list the inland manufacturers with no more than 100 employees and then select over 250 companies at random. Remove those with invalid addresses with a result of identifying 241 companies for mailing. Owners of these companies were targeted for response. A questionnaire with a self-addressed envelope solicited their response with a letter that indicated that they would be informed of the results of the findings. 
The topics covered by the questions in the survey were selected as indicative of aspects of culture that are predominantly found in the China and may impact business ethics. Beliefs in Confucianism, Taoism, Sunzi Bingfa, Heavenly Power, Guanxi, and Face were considered aspects of the Chinese culture that may be undergoing change as a result of the conversion from the planned economy to a market economy. These aspects are importance to the Chinese culture and could provide insights as to how Chinese business ethics may be evolving.

Data was gathered at Beijing Tong University and entered into an Excel spreadsheet. Data was analyzed using Excel and Data Desk software by the authors in both China and the United States. These independent efforts provide corroboration of the findings.

The data has been analyzed and the following section has been developed using the results of the analysis. A brief synopsis of the statistic is provided for each of the ethical considerations.

\section{Limitations}

The survey was mailed to over 5,000 businesses at random. There were no controls established to ensure representative samples were obtained from the specific groups selected for inclusion in the research. Accordingly, respondents do not necessarily reflect their particular business type or location, thus making correlation with those variables difficult and results tenuous. A sample size of 90 respondents limits the ability to generalize to the whole population of businesses in China.

\section{Ethical considerations}

Many aspects of a culture influence business ethics. The study of ethics suggests that determining right from wrong may be influenced by a countries culture, which is shaped by philosophical leanings of the society. Six areas of culture were considered in this study to provide insights into the ethical behavior of Chinese businesses. The six areas addressed in this research were selected for their specific relationship to the Chinese culture and they are: Confucianism, Taoism, Sunzi Bingfa, Heavenly Power, Guanxi, and Face. Each is addressed with a brief description and the results of the research findings, which indicate any change in the importance between 1990 and 2006. The importance or frequency of use is for each time period is presented for each ethical consideration. Conjecture as to the reason for the changes are left to the reader, although some ideas are presented in the conclusions.

\subsection{Confucianism}

Confucianism refers to the system of thought, which was developed about the 6th Century B.C. by Kong Fuzi (Latinized to Confucius). Confucianism is a system of values, which, relates to the whole world and influences the family, society, economics, and the government. The basic ideas evolved through the centuries and were modified for practical applications. There are six basic tenets of Confucianism: compassion, filial piety, righteousness, propriety, loyalty, and reciprocity. Briefly, compassion is the fundamental value, which relates to the way people relate to each other. It is basically the Golden Rule: "Do unto others what you would like for them to do unto you". Filial piety is the love, care and consideration that a child owes to their parents. A child should sacrifice their own well being for the good of the parents. Righteousness means to act for the greater good of family, society and the nation. Propriety is doing the right thing at the right time. Treating others properly gives rise to harmonious relations. Loyalty to country is similar to Western ideals in regards to country. Loyalty in Confucianism also must be considered with family and friends as well. Reciprocity is the idea that relationships are important and that persons are enmeshed in complex webs of interactions with others.

Confucianism gave the Chinese society a humanistic way of looking at the entire realm of ethical behavior including family, society and nation. Economics, religion, family, government, and education were all included in the philosophy and it lasted for over 4,000 years. Business behavior was strongly influenced by Confucianism. Family owned businesses were passed from generation to generation. The Matriarch or Patriarch of the business was bound by the principles of compassion, righteousness, and reciprocity, as they were responsible for the well being of the business and its employees. Loyalty often meant hiring their children, other family and friends. Propriety was a basis for "face" and reciprocity was a foundation for guanxi, or "relations".

\section{Insert Table 1 here \\ Insert Figure 1 here}

Based on the authors' survey, shown as Tab.1 and Fig.1, the importance of Confucianism is on the rise in business from 1990 to 2006. On a scale from 1 to 4, the business respondents rated the importance of Confucianism as 2.53 in 1990 and 3.29 in 2006. This .99 statistically significant increase is consistent with the often, suggested proposition that Confucianism has experienced a resurgence since the establishment of a market economy in recent years. This finding is not necessarily consistent with the seeming materialistic, self-centered ideas of a market economy whereby individuals take care of themselves first and family and others secondly. Importance of the family still exists, especially in the rural areas. Many factory workers provide subsistence living for family members left behind in rural areas, which 
may be based in the strong belief in the Confucius virtue of filial piety. Business owners are known to allow workers to return to their homes for brief periods to allow them to care for their families.

\subsection{Taoism}

Taoism is an ancient religion of China with history dating back to the 6th Century, B.C. "Tao" (pronounced "Dow") is a force, not a person. Tao refers to a formless non-being and a power which envelopes, surrounds and flows through all things, living and non-living. The Tao regulates natural processes and nourishes balance in the Universe (Schipper, 2000). The harmony of opposites (e.g. no love without hate, no light without dark) is recognized and ambiguity is seen as the natural state. Everything in the universe has its own power or virtue, which brings harmony and a natural order to the world. Humans may realize their inner being as part of the Tao and live a life of harmony. Taoism's focus on nature and the natural order is consistent with both Confucianism and many of the beliefs of Buddhism.

Taoism flourished during the Tang Dynasty and became integrated into the civil life of the Chinese society during the Ming Dynasty. Taoist temples and city gods became a major influence on the life of much of the population of China. Western influence during the Qing Dynasty began the destruction of Taoism. The religion became to be recognized as a feudal superstition. With the relative liberalization began under Deng Xiaoping's regime, Taoism has begun to function again in China and some of the early Taoist philosophy has migrated to the West (Cheng, 2004).

Taoism emphasizes harmony with nature and within society. This forms a basis in which business should benefit society and greed is discouraged. Businesses should provide the basic needs of society without unordinary benefit to the individual. "Taoism chimes well with a free market economy" ("The ancient art of making money", 2001). It has been suggested that Taoism is resurging in China.

\section{Insert Table 2 here}

\section{Insert Figure 2 here}

Based on the authors' survey, shown as Tab.2 and Fig.2, the importance of Taoism is on the rise in business from 1990 to 2006. On a scale from 1 to 4, the business respondents rated the importance of Taoism as 2.30 in 1990 to 3.09 in 2006. This .99 statistically significant increase is consistent with the often, suggested proposition that Taoism has experienced a resurgence in recent years. It is not clear that this resurgence is related to the change from a centrally planned economy to a market economy or it may be a reaction to a new freedom to again practice religion in China. Concern for gaining material wealth is not a tenant of Taoism but has become a powerful influence in the Chinese society. The Taoist ideas of "do nothing to govern" and "keep still to defeat movement" may becoming a more popular thought than occurred during the centrally planned economy prior to 1978.

\subsection{Sunzi Bingfa}

Sunzi Bingfa is a well-known book on military science in China. The Art of War is one of the most popular military classics in both Asia and the West. Written by Sun Wu (6th cent BC), managers have employed the ideas as a guide for negotiations in the economic arena. Some of the often, business relevant Sunzi Bingfa tenets that should be considered and modified to fit business strategy include:

- $\quad$ All business is based on deception.

- Hold out baits to entice the opponent. Feign disorder, and crush him.

- If your opponent is of ill temper, seek to irritate him. Pretend to be weak, so that he may grow arrogant.

- Attack your opponent where he is not prepared: appear to be coming from a position, which is not expected.

- The successful business negotiator makes many calculations before the negotiation. The negotiator who makes few calculations beforehand will lose at the negotiating table.

\section{Insert Table 3 here}

\section{Insert Figure 3 here}

Based on the authors' survey, shown as Tab.3 and Fig.3, the importance of Sunzi Bingfa is on the rise in business from 1990 to 2006. On a scale from 1 to 4, the business respondents rated the importance of Sunzi Bingfa as 2.63 in 1990 to 3.39 in 2006. This .99 statistically significant increase is consistent with the emphasis on conducting business to win. There have been numerous writings with assertions by Western business negotiators that Chinese negotiators are excellent in their craft.

\section{$3.4 \mathrm{God}$}

The Chinese have been influenced by the beliefs in many gods. These deities are many and belief in them has varied throughout history. Deities have special powers to help overcome problems and in some cases provide access to immortality. Traditional Christian and Islam belief in God suggests a supreme being created heaven and earth. God is omnipresent, omniscient, all-powerful, loving, and merciful as well as other attributes according to most monotheistic 
religions. Christianity and Islam have existed in China for several hundred years. "The first Jesuit mission in China began in 1583 under the leadership of Matteo Ricci, a famous Jesuit from Italy." (Liu, 2005). 3 to $4 \%$ of the Chinese population are estimated to be Christian ("The world factbook", 2006). Islam was introduced into China during the Tang and Song Dynasties (618-1279).

"Traditionally, the Communist Party allowed membership in five officially approved religions: Buddhism, Taoism, Islam, Protestant Christianity and Catholicism.“ (Elegant, 2006). Liberalization of religion has been a continuing debate within the party but some religious freedom has been granted. "The flowering of Chinese Christianity reflects a wider religious awakening." (Elegant, 2006) and the belief in a heavenly power appears to be on the rise.

\section{Insert Table 4 here}

\section{Insert Figure 4 here}

Based on the authors' survey, shown as Tab.4 and Fig.4, the importance of a heavenly power is on the rise in business from 1990 to 2006. On a scale from 1 to 4, the business respondents rated the importance of a belief in a heavenly power, which can control your fate and help business to succeed as 1.42 in 1990 to 1.58 in 2006. While this less than .90 statistically significant increase in the belief in a heavenly power, it does indicate that there is considerable increase in the belief in a heavenly power. A 2006 rating for a heavenly power of 1.58 remains a relatively low ranking compared to a 2006 Confucianism rating of 3.29 and 2006 rating of Taoism of 3.09. It is not clear how this increase in the belief of a heavenly power is affecting business management, if at all.

\subsection{Guanxi}

Guanxi means good connections or relationships and may be established through family or friends. Guanxi may be considered a friendship with an expected exchange of favors (Pye, 1992). This concept suggests that a continuing interpersonal relationship exists with favors being traded without a contract. The depth of the relationship varies and thus the quality of the relationship is dependent on personalities. This aspect of Chinese culture has provided the basis for business dealings in China throughout history. As Eric Tsang noted "executives found that the businessmen believed that once good guanxi had been established, a number of benefits would follow."(Tsang, 1998, p. 67). Guanxi continues to be a major consideration in Chinese business. "In the West, relationships grow out of deals. In China, deals grow out of relationships "(Vanhonacker, 2004, p. 48). Maintaining relations networks within businesses and with the government is important.

With the economic reforms, some lessening of the importance of guanxi related to dealings with government officials has been suggested. McClenahen argued three reasons for this decline in importance: the Chinese government's emphasis on the rule of law; procedural safeguards, such as the Administrative Litigation Law and the Licensing Law, designed to curb abuses of power; and the crackdown on corruption (McClenahen, 2004). Guanxi networks permitted legal as well as illegal activities to be conducted often between business partners and government officials. Often, corrupt business practices were overlooked by authorities, as the favors were sufficient to look the other direction when a guanxi partner was acting unethically.

It is apparent that the use of Guanxi is in question. The use of Guanxi may be difficult to measure as various aspects are considered. Guanxi with friends and relatives may be considered acceptable while dealings with government officials in a "shady" manner may be considered differently. The question included in this research survey suggested that dealings with government officials were to be of primary importance.

\section{Insert Table 5 here}

\section{Insert Figure 5 here}

Based on the authors' survey, shown as Tab.5 and Fig.5, the frequency of guanxi use is on the rise in business from 1990 to 2006. On a scale from 1 to 4 , the business respondents rated the frequency of use rising from 2.95 in 1990 to 3.17 in 2006 with a paired t-test significance of .1093. While this increase is less than .90 statistically significant, the frequency of use of guanxi is considerable in business management in 2006. Other studies have indicated that guanxi use may be on the decline as government crackdowns on corruption has severely limited the opportunity for unethical behavior of officials and has had a positive result in reducing the instances of illegal behavior. There have been suggestions that guanxi use is on the decline while others have suggested that it may be on the increase. Based on this survey, guanxi use is increasing.

\subsection{Face}

Face is an essential component of the Chinese society. Having face means having a high status in the eyes of one's associates, and is an important to for having personal dignity. "Face" is the term used to describe ones dignity and prestige and is very important (Woo, 1999). The Chinese are acutely sensitive to gaining and maintaining face in all aspects of social and business life. Face is a prized asset, which can be given, lost, taken away or earned. Causing someone to lose face can terminate business deals. One can easily cause someone to lose face by an insult or criticism 
in front of others. Just as face can be lost, it can also be given by commending someone in front of their' peers. "Giving face" to an associate by complementing them in front of others or while alone enhances their reputation and prestige (Ambler, 2000), thus giving face is an excellent means to improve guanxi.

\section{Insert Table 6 here}

\section{Insert Figure 6 here}

Based on the authors' survey, shown as Tab.6 and Fig.6, the importance of "face" is on the decline in business from 1990 to 2006. On a scale from 1 to 4, the business respondents rated the importance of "face" as 3.04 in 1990 to 2.77 in 2006. This .90 statistically significant decrease is consistent with the often, suggested proposition that business people are no longer required to give face to conduct business with "superiors" as contract relationships are of more import than in the past. This apparent reduction in the importance of "face" does not appear consistent with the increase in importance of guanxi as face is often a means to improve guanxi.

\section{Conclusions}

Since 1990, Chinese business culture is changing based on the results of this survey of small and medium sized businesses. The six aspects of culture considered here indicate that significant increases exist in the importance of Confucianism, Taoism, Sunzi Bingfa, and Guanxi. Belief in a Heavenly Power is increasing to some degree while the importance of Face is decreasing.

Confucianism is increasing in importance in the Chinese business community. There are several tenets of Confucianism that suggest business ethics could be affected. The matriarchs and patriarchs of small companies sometimes take care of their workers at substantial expense. Most often, it is difficult to ascertain whether the true intent of the employers in these cases are compassion or simply a good business decision to ensure employee loyalty and/or necessity to minimize harm to the worker so that they may continue to be productive. Children must show respect and ensure for the well being of their parents. It has been noted that in many factories, the children wage earners send money home to assist in the care of their parents and other siblings. Family loyalty is often observed as positions in companies. This nepotism is found in both urban and rural settings. The concept of reciprocity remains a major influence in Chinese business.

Taoism tenets suggest that business leaders should seek harmony within nature and society. The survey statistics indicate a rise in the belief that Taoism is important. Translating this apparent increase in importance is not obvious. Negotiations with Chinese business leaders may be almost confrontational. Chinese negotiators may be exhibiting the harmonious concept when the word "no" is avoided even when "no" is the true answer to a business idea. Harmony within a guanxi network is consistent with Taoism.

Although Sunzi Bingfa was a well-known book on military science, its' apparent increase in importance appears consistent with Chinese business practice. Deception in business negotiations is commonplace. Appearing to change positions during negotiations by coming full circle from an initial position confuses most Western business leaders. The increase of importance of Sunzi Bingfa in the conduct of Chinese business may be a result of increased dealings with the West and the success that the strategy has achieved.

While not statistically significant to the .90 level, a belief in a heavenly power by Chinese business leaders appears to be increasing. It is not apparent that any conclusion can be reached on the affect of any increase. It has been suggested that an overall increase in spiritual ideas may be encompassing the Chinese society in general.

The use of guanxi is increasing. This is consistent with the findings of increased importance of Confucianism and Taoism. The specific question asked by the survey was directed at the use of guanxi in relation to obtaining influence with government officials or others in positions of authority. It is not suggested that the influence being pursued is an illegal or unethical act. It is important to have connections in high places so that business dealings can be made in a more, timely manner.

The importance of "face" is declining. "Giving face" or "saving face" has always been an important aspect of the Chinese society and very important in business. Showing respect for ones associates has been considered paramount in business dealings. The apparent decline may be a result of dealings in which the relationship is on a more Western business-to-business style in which both parties are attempting to show a less emotional approach to the deal. Especially the younger business negotiators have become somewhat more arrogant and look at contractual arrangements as the real objective as opposed to feeling the need to be subservient to higher ranking authority. It is not a matter of disrespect; it is a matter of establishing an equal footing when conducting business.

These conclusions are those of the authors. These conclusions are based on the data as well as the experiences of the authors and other researchers. It is likely that other interpretations can also be equally valid. 


\section{References}

Ambler, T., \& Witzel, M. (2000). Doing Business in China (2nd 2004 ed.). New York: RoutledgeCurzon.

Cheng, C.-Y. (2004). Dimensions of the dao and onto-ethics in light of the ddj. Journal of Chinese Philosophy, 31(2), 143-182.

Elegant, S. (2006, 8/28/2006). The war for China's Soul. Time, 168, 40-43.

Liu, Y. (2005). Seeing God Differently: Chinese piety and European modernity. History of Religions, 45(1), 29-44.

McClenahen, J. S. (2004). China's Cultural Challenge. Industry Week, 253(4), 38-45.

Pye, L. (1992). Chinese Commercial Negotiating Style. New York: Quorum Books.

Schipper, K. (2000). Taoism. Humanities, 21(6), 35-39.

The Ancient art of Making Money. (2001, 04/07/2001). Economist, pp. 5-5.

The World Factbook. (2006). In CIA (Ed.): United States Government.

Tsang, E. W. K. (1998). Can Guanxi Be a Source of Sustained Competitive Advantage for doing Business in China? Academy of Management Executive, 12(2).

Vanhonacker, W. R. (May/Jun. 2004). Guanxi Networks in China. The China Business Review, 31, 48-53.

Woo, H. S. a. P. h., Celine. (1999). Cultural Characteristics Prevalent in the Chinese Negotiation Process. European Business Review, 99, p. 313.

Wu, J. (2005). Understanding and interpreting Chinese economic reform. Mason, Ohio: Thomson South-Western. 
Table 1. Frequency breakdown of Confucianism

\begin{tabular}{|c|c|c|c|c|c|c|}
\hline \multirow{2}{*}{\multicolumn{2}{|c|}{ Year }} & \multicolumn{4}{|c|}{ Key } & \multirow{2}{*}{$\begin{array}{c}\text { Means } \\
\text { (Importance } \\
\text { Rating) }\end{array}$} \\
\hline & & 1 & 2 & 3 & 4 & \\
\hline \multirow[t]{2}{*}{1990} & Number & 11 & 31 & 25 & 15 & \multirow[t]{2}{*}{2.53659} \\
\hline & Group Count $\%$ & 13.415 & 37.805 & 30.488 & 18.293 & \\
\hline \multirow[t]{2}{*}{2000} & Number & 0 & 25 & 41 & 17 & \multirow[t]{2}{*}{2.90361} \\
\hline & Group Count $\%$ & 0 & 30.120 & 49.398 & 20.482 & \\
\hline \multirow[t]{2}{*}{2006} & Number & 3 & 13 & 29 & 45 & \multirow[t]{2}{*}{3.28889} \\
\hline & Group Count \% & 3.333 & 14.444 & 32.222 & 50.000 & \\
\hline
\end{tabular}

Note. $1=$ Not Important, $2=$ Not Very Important, 3=Important, 4=Very Important

Table 2. Frequency breakdown of Taoism

\begin{tabular}{|c|c|c|c|c|c|c|}
\hline & \multirow[t]{2}{*}{ Year } & \multicolumn{4}{|c|}{ Key } & \multirow{2}{*}{$\begin{array}{c}\text { Means } \\
\text { (Importance } \\
\text { Rating) }\end{array}$} \\
\hline & & 1 & 2 & 3 & 4 & \\
\hline \multirow[t]{2}{*}{1990} & Number & 15 & 35 & 24 & 8 & \multirow[t]{2}{*}{2.30488} \\
\hline & Group Count \% & 18.293 & 42.683 & 29.268 & 9.756 & \\
\hline \multirow[t]{2}{*}{2000} & Number & 6 & 26 & 42 & 9 & \multirow[t]{2}{*}{2.65060} \\
\hline & Group Count \% & 7.229 & 31.325 & 50.602 & 10.843 & \\
\hline \multirow[t]{2}{*}{2006} & Number & 8 & 13 & 32 & 37 & \multirow[t]{2}{*}{3.08889} \\
\hline & Group Count \% & 8.889 & 14.444 & 35.556 & 41.111 & \\
\hline
\end{tabular}

Note. $1=$ Not Important, $2=$ Not Very Important, 3=Important, 4=Very Important

Table 3. Frequency breakdown of Sunzi Bingfa

\begin{tabular}{|c|c|c|c|c|c|c|}
\hline & \multirow[t]{2}{*}{ Year } & \multicolumn{4}{|c|}{ Key } & \multirow{2}{*}{$\begin{array}{c}\text { Means } \\
\text { (Importance } \\
\text { Rating) }\end{array}$} \\
\hline & & 1 & 2 & 3 & 4 & \\
\hline \multirow[t]{2}{*}{1990} & Number & 8 & 31 & 19 & 16 & \multirow[t]{2}{*}{2.63095} \\
\hline & Group Count \% & 9.524 & 36.905 & 34.524 & 19.048 & \\
\hline \multirow[t]{2}{*}{2000} & Number & 2 & 11 & 45 & 16 & \multirow[t]{2}{*}{3.13095} \\
\hline & Group Count \% & 2.381 & 13.095 & 53.571 & 30.952 & \\
\hline \multirow[t]{2}{*}{2006} & Number & 2 & 9 & 30 & 48 & \multirow[t]{2}{*}{3.39326} \\
\hline & Group Count \% & 2.247 & 10.112 & 33.708 & 53.933 & \\
\hline
\end{tabular}

Note. $1=$ Not Important, $2=$ Not Very Important, 3=Important, 4=Very Important 
Table 4. Frequency breakdown of God

\begin{tabular}{|c|c|c|c|c|c|}
\hline & \multirow[t]{2}{*}{ Year } & \multicolumn{3}{|c|}{ Key } & \multirow{2}{*}{$\begin{array}{c}\text { Means } \\
\text { (Importance } \\
\text { Rating) }\end{array}$} \\
\hline & & 1 & 2 & 3 & \\
\hline \multirow[t]{2}{*}{1990} & Number & 55 & 21 & 7 & \multirow[t]{2}{*}{1.42169} \\
\hline & Group Count \% & 66.265 & 25.301 & 8.434 & \\
\hline \multirow[t]{2}{*}{2000} & Number & 49 & 29 & 6 & \multirow[t]{2}{*}{1.48810} \\
\hline & Group Count $\%$ & 58.333 & 34.524 & 7.143 & \\
\hline \multirow[t]{2}{*}{2006} & Number & 51 & 24 & 14 & \multirow[t]{2}{*}{1.58427} \\
\hline & Group Count \% & 57.303 & 26.966 & 15.730 & \\
\hline
\end{tabular}

Note. 1: I do not believe, I can control my fate myself; 2: Do not care ordinarily, but hope sometimes heavenly power could help me; 3: I believe and remember it all the time.

Table 5. Frequency breakdown of Guanxi

\begin{tabular}{|c|c|c|c|c|c|c|}
\hline \multirow{2}{*}{\multicolumn{2}{|c|}{ Year }} & \multicolumn{4}{|c|}{ Key } & \multirow{2}{*}{$\begin{array}{c}\text { Means } \\
\text { (Importance } \\
\text { Rating) }\end{array}$} \\
\hline & & 1 & 2 & 3 & 4 & \\
\hline \multirow[t]{2}{*}{1990} & Number & 5 & 24 & 23 & 30 & \multirow[t]{2}{*}{2.95122} \\
\hline & Group Count $\%$ & 6.098 & 29.268 & 28.049 & 36.585 & \\
\hline \multirow[t]{2}{*}{2000} & Number & 0 & 21 & 31 & 33 & \multirow[t]{2}{*}{3.14118} \\
\hline & Group Count $\%$ & 0 & 24.706 & 36.471 & 38.824 & \\
\hline \multirow{2}{*}{2006} & Number & 2 & 23 & 22 & 42 & \multirow{2}{*}{3.16854} \\
\hline & Group Count $\%$ & 2.247 & 25.843 & 24.719 & 47.191 & \\
\hline
\end{tabular}

Note. 1: Never; 2: Sometimes; 3: Infrequently; 4: Frequently

Table 6. Frequency breakdown of Face

\begin{tabular}{|c|c|c|c|c|c|c|}
\hline \multirow{2}{*}{\multicolumn{2}{|c|}{ Year }} & \multicolumn{4}{|c|}{ Key } & \multirow{2}{*}{$\begin{array}{c}\text { Means } \\
\text { (Importance } \\
\text { Rating) }\end{array}$} \\
\hline & & 1 & 2 & 3 & 4 & \\
\hline \multirow[t]{2}{*}{1990} & Number & 8 & 21 & 15 & 40 & \multirow[t]{2}{*}{3.03571} \\
\hline & Group Count $\%$ & 9.524 & 25.000 & 17.857 & 47.619 & \\
\hline \multirow[t]{2}{*}{2000} & Number & 4 & 25 & 33 & 22 & \multirow[t]{2}{*}{2.86905} \\
\hline & Group Count $\%$ & 4.762 & 29.762 & 39.286 & 26.190 & \\
\hline \multirow[t]{2}{*}{2006} & Number & 5 & 37 & 22 & 26 & \multirow[t]{2}{*}{2.76667} \\
\hline & Group Count \% & 5.556 & 41.111 & 24.444 & 28.889 & \\
\hline
\end{tabular}

Note. 1: Not Important; 2: Sometimes Important; 3: Often Important; 4: Very Important 

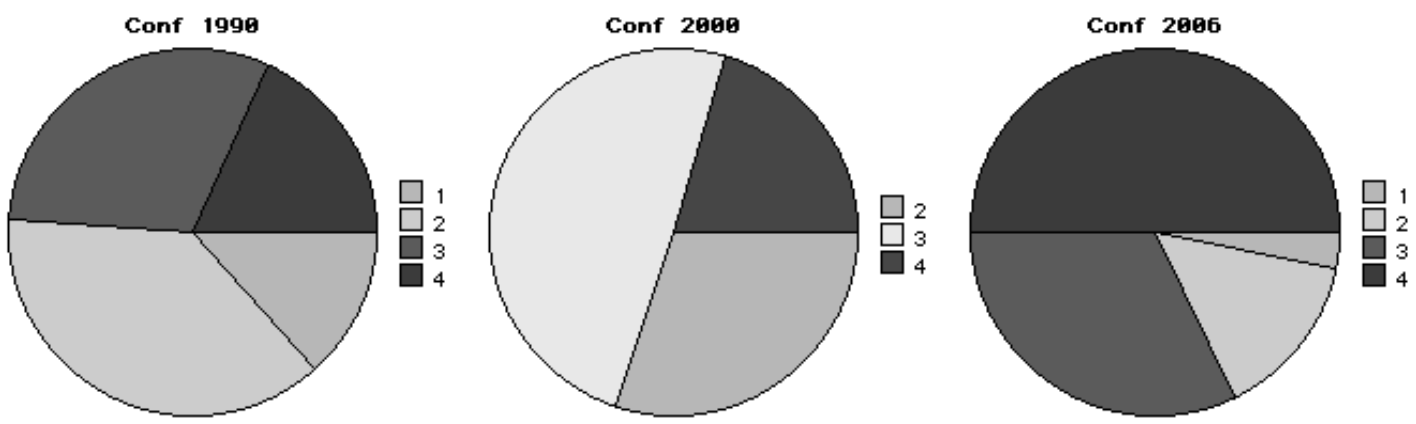

Figure 1. Frequency breakdown of Confucianism
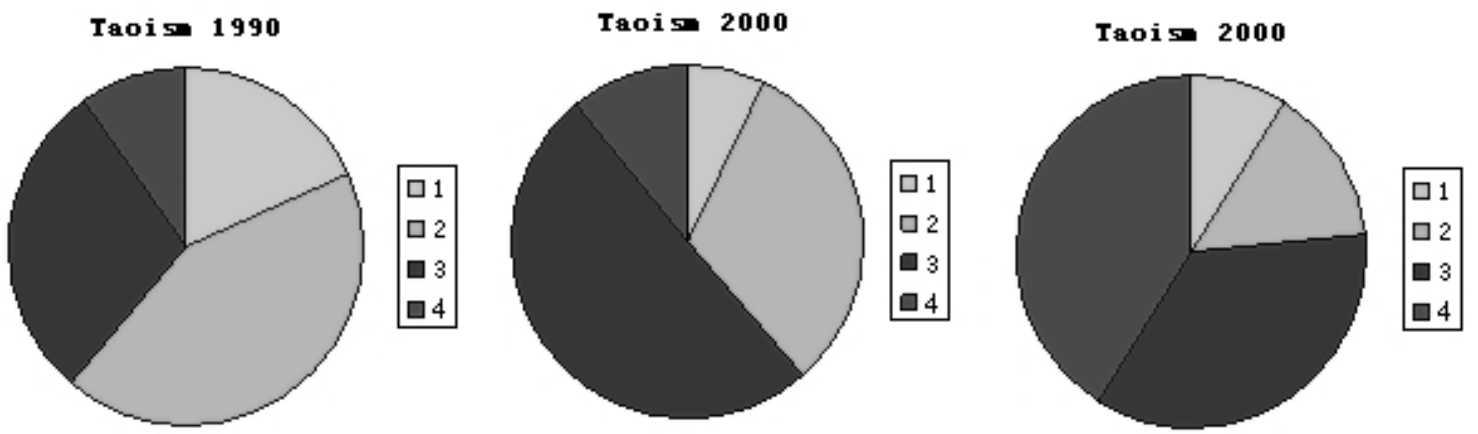

Figure 2. Frequency breakdown of Taoism
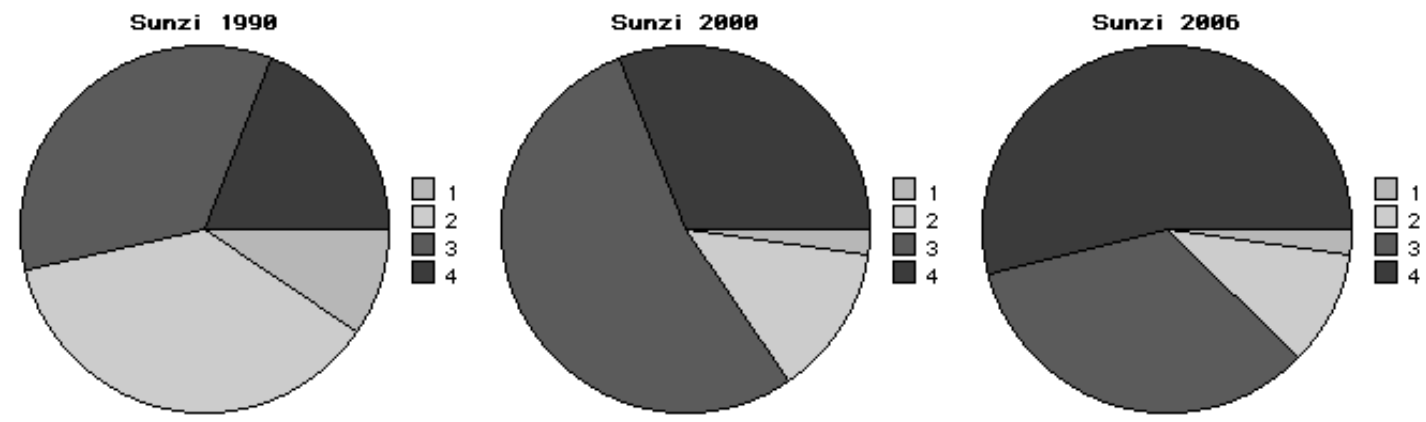

Figure 3. Frequency breakdown of Sunzi Bingfa
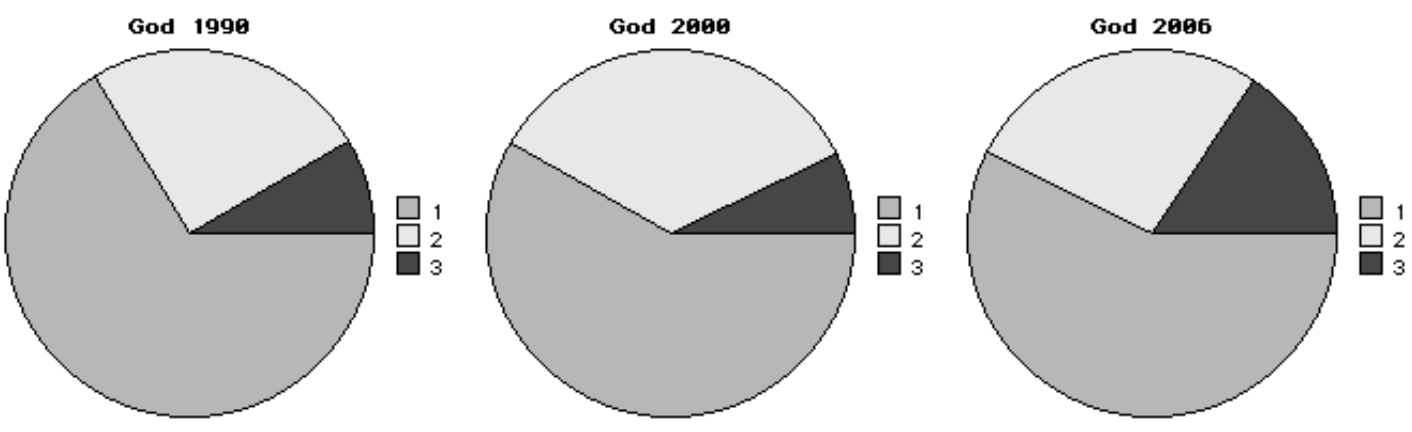

Figure 4. Frequency breakdown of God 

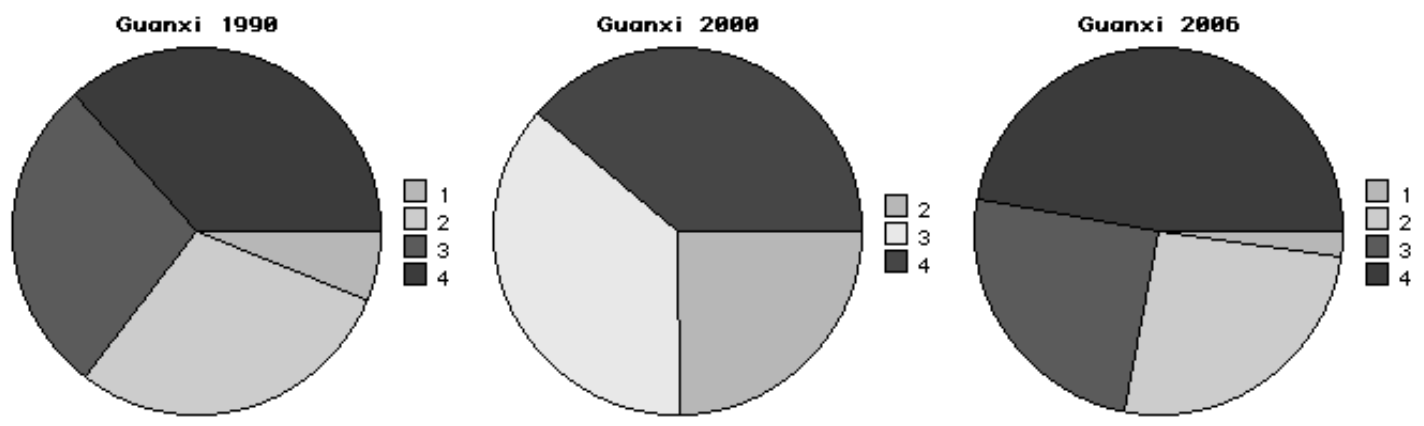

Figure 5. Frequency breakdown of Guanxi
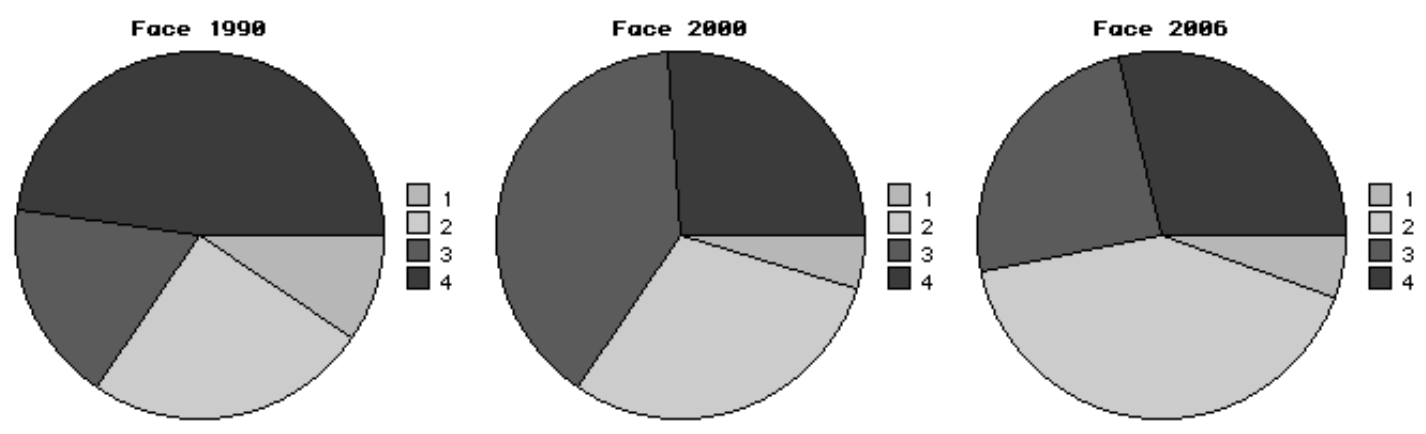

Figure 6. Frequency breakdown of Face 